\title{
The days of poetry are running out
}

\section{Mozid Mahmud}

\author{
Executive Director of Organization for Social Advancement \& Cultural Activities (OSACA) \\ Panel President of Writers Club, Dhaka \\ Head of Char Niketon Education Village
}

\begin{abstract}
The purpose of writing this essay is to make an observational decision about where the future of poetry will stand due to the unprecedented development of technology and science. In this article, I tried to show how the poems got separated after the invention of printing from the early and medieval poems. In spite of using computer equipment, especially poetry writing, poetry is changing its old anatomy. There is considerable reason to think about this change that technology has a close relation with the writing of poetry. As a result, a visible change in the poems of poetry that has been used so far is a visible change. To prove the reality of my project, I have tried to illustrate the concept of change of poetry, the history of printing, the history of anthropology, language and myths. But even though this fact is still a huge change, the concept of poetry in human mind does not seem to change.
\end{abstract}

Keywords - Poetry, poem, poet, society, compose, existentialism, metaphysics, languages, biological existence, religious, mortal, printing press.

For not allocating any place to the poets and their creation in his ideal state ${ }^{1}$, Plato has been rebuked by the poets over the past 2500 years. The poets can be critical of the people living in the society very often because they possess the wonderful gift of writing. There is nothing to be astonished at the poet's being vocal about their creation. Despite that, the poets are unwilling to expound why writing poems is better than other works.

Nobody considers whether the literary piece is going to be good or bad while embarking on writing. Without any external pressure or material gain, the poet assigns himself or herself to writing. If the poet goes without composing any poems, it will not be harmful for him or her. Putting aside the inspiration coming from within is impossible to be neglected to the poet. In such a condition, putting something in black and white brings freedom. The unexplainable part of the world does not constitute the entire literary manufacture of a poet. Even explaining every aspect of a literary work may become impossible for the poet. But the dynamics of perception take a creative shape at an auspicious time which then enables the poet to embrace truth. The continuation of this perception results in making a poet. At this stage, the poet's recurring perception wants to be expressed linguistically. The poet also goes on to transmit his or her perception to the people speaking the same language.

We can go further into what sort of logic the poet organizes in a bid to fulfill his or her task. In fact, a poem is a piece of work and setting the process of doing that work in motion is the soul work of the poet in the first place. The word 'art' has been willingly omitted in the previous lines. Poetry is finally considered to be reader oriented. It will be more specific to say that the fame of being a poet is more reader oriented than the composition of poetry itself. The reason behind this is the fact that poetry and fame are different from each other. The presence of another person is totally irrelevant at the time of composing a poem. But the existence of poetry is dependent on the acceptance of the readers. If a poem does not have the magnetism required to draw the readers to it, it cannot be a poem at all. In the prosperous domain of poetry, compulsion and salary have nothing to do. It is also true that poetry will suffer from the existential crisis for want of readers. Even the poet may lose his or her interest in reading a poem of his or her own composition. In the first phase of creation, the poet is moved by a kind of poetic spell. The poet puts into words the struggle between his or her inner self and the external world. Unlike the majority living in our society, the poet is gifted with the power of recording the struggle with the help of language. The poet does not create any language. Since a language survives through the mutual partnership of the people speaking the same language, the poetry composed in that language enjoys the power of promoting activism among the users of that language. But the lack of a universal definition of the poet and his or her poetry has made it impossible to turn down the claim of the poet. Poetry is not such a science which can be proved false. Furthermore poetry is not like that field of metaphysics which is not tied to religion or supernaturalism ${ }^{2}$. Science leaves a kind of implication in its hypothesis; in case of any exception to that, the outcome of the whole project becomes jeopardized .But this is not possible for the poet.

Can we place the poetry of the poets who are known or unknown to us and who lived in olden times such as Homer 
or Valmiki, Kalidasa or Euripides, Chandidasa or Chaucer, Rumi or Tagore and Nazrul and Baudelaire in the same category? How can we minimize the effect of not only subject and style but also person and time through this process? Is generalization possible between the subject and style of an epic and a lyric? The lyricists of our contemporary world have no need to play the same role like the writers of epic, the setting of which is the ancient world. In addition to that, the post Rabindranath-Nazrul lyrical poems can't truly conform to the genre since there is no lyrical properties in them. It is known to us that poetry is the oldest medium of literature in every language. So we can't leave the thought about the depth of the source of this medium. We can't say why the ancient people choose poetry as a medium of literary expression. The availability of alternatives is a must if someone wants to choose something. We also don't know whether the poets of the ancient times had any alternatives. So, they choose poetry from a variety of alternatives is not exactly the case. I think that becoming a poet was intertwined with the first attempt at becoming a true human being by our forefathers ${ }^{3}$.

Humans are the only creature in this world who has struggled a lot to achieve the level of the present age. Language has fostered mankind's achievement. Language has been transmitting the experience and memory of the humans down the ages. The work of adding the wisdom and experience drawn from the past to the current wave of knowledge is done with the help of language. This flow is interlinked with the existence and nature of mankind. Why did this thought enter into the humans? Almost all the creatures use a few words and codes on a limited basis. But, it is impossible for them to achieve the most sought after excellence at a regular or systematic interval. Even if the aforesaid creatures have the ability to pronounce a word or two, they are unable to surpass the complexity of interpreting it in various contexts. The consequence is the non application of the previous experience or knowledge in the life of these creatures. The existence of the idea of 'a human being', which we are carrying forward, almost depends on the charismatic power of the languages. Humans have got extra advantages over other creatures through using a reliable medium of communication i.e. language. In addition to maintaining day to day communication, language has constructed a bridge across the river running between the past and the future. At that time when paper and alphabet were not invented, what did the Humans do in order to fill up the gap between the past and the future? To me, the mystery behind the creation of poetry is hidden in this question. So, it can be said that humans have created an eternal world of poetry distinct from the limited biological one and that very world lives on language. How is it possible to sustain the knowledge carried by language without the help of the printing presses, scripts or other devices meant for protection in this age? Before the invention of scripts, humans used their memory for the purpose of protecting their special knowledge accrued from many clans of languages. Humans can commit the knowledge gained from the material world as well as the language spoken by others to their memory without any substantial change. There is the presence of a kind of internal grammar which facilitates the way our brain responds to the absorption of language and how that grammar is created is not known to us. Linguists from Saussure to Chomsky have tried to know about the nature of that grammar $4^{4}$. I think poetry bears more than the aspiration out of which language was created; it resembles the way which humans use to protect their issues. The reason behind this may be the mortality of our life. By continuing the process of reproduction, Humans actually want to shield themselves against death. This realization goes parallel to the existence of a human being. Humans engage themselves in variety of works so as to secure their existence. But the overall existence of a human being is not dependent on the biological aspect alone. In addition to the biological existence, the existence of thought and realization are also very important in the case of humans because they want to leave not only biological survivors but also ideological survivors 5 . This was not possible before the invention of alphabets or scripts. Then, the only means was the memory. Humans needed to maintain some rules so that the picture of language could be absorbed into the memory permanently. It is very easy for the humans to commit the sentences full of rhythm and alliteration to their memory. When those stanzas which are very easy to be framed into the memory come to us, the glands of our brain turn excited and such a style is formed which is quite different from our day to day conversation. This results in the creation of poetry. I want to regard the process through which poetry is created as the ancient printing press. This is also the factor which explains why poetry preceded prose at that time when the usage of the printing presses and things to write on were not in vogue. How the humans learnt the art of composing poetry is both complex and unsettled like the creation of language. Language is such a medium which originates from our body. But, we can't touch it inside or outside our body. Moreover these invisible strings of words construct a bridge of communication between two visible humans. One can then understand the intention of the other. The existence of a language can not be imagined without a biological body. On the other hand languages have no body which can be touched. 
But, it is true that humans had no knowledge about rhythm or rhyme when they started writing poetry. Rhythm has been an instinctive feature of the humans at the time of giving their speeches a permanent shape. As a result, not only epics but also ethics, law and history have been composed in poetry from generation to generation in ancient times. We all know about the great epics which were enriched by the poets from various ages. Some poet gifted with the extraordinary poetic license might give those epics the form with which we are acquainted now. Mankind's maximum growth in the field of thought is found in those epics. The reason is that either there is no need for everybody to protect the day to day happenings or our brain cannot store that volume of content. So, the epics of the ancient period are replete with those kinds of similes or the supreme level of imagination which doesn't conform to the reality and makes us think what kind of reality has given rise to this imagination ${ }^{6}$. Our material consciousness at times cannot fathom the practicality of the ancient myths and the characters found in them and this deviation from practicality also makes us wonder ${ }^{7}$. But, it will be wrong to say that only imagination has provided the poets with the required materials. It is proved by the graphic description those epics gave about the social and political reality of that age. Moving a bit further from the characters of the age of Grecian myths to the age of Socrates will make us observe that the plays composed by Euripides or Sophocles maintain a good relation with reality. The Oedipus complex which was first seen in the plays of Sophocles has not lost its appeal yet. These playwrights and poets even referred to Socrates and his disciples in their writings. In the Indian mythology, the battle between the korus and the Pandavas or the vendetta between the Yadavs and the Raghus has been historically authenticated in the same manner ${ }^{8}$. Though we can not explain whether the presence of ever changing man eaters, ghosts and mammoth creatures was real or not, we can understand that these things are beyond explanation like the magic realism, a Hispanic literary movement in the same way also. In spite of being devoid of reality, those super human elements cannot be completely aliens. Humans are such a creature who cannot live in reality always. The real life becomes a purgatory to the humans if it is not covered with imagination. Humans would dive into the trend of death and suicide then ${ }^{9}$. As a result, they always want to attach themselves to the immortal power. This immortality is what "poetry and art" $\operatorname{are}^{10}$. This immortality does not refer to any religion or the idea of the creator in any religion to me. This perception is an immortal consciousness in itself. Being trusted by air, this consciousness mingles with the super fast ray of light and roams in the outer space. The truth that "I am mortal" is www.ijels.com a mournful cry in a human being's consciousness. Is the ascension into heaven by Gilgamesh, a king of Mesopotamia or by Yudhisthira, a king in the Hindu epic Mahabharata anything other than the same pain? Humans have not composed poetry or other genres of literature in fear of death or to glorify it. They also have the latent desire for being into the immortal lines which have been composed by them. Even Baudelaire's hell and syphilis are the result of this antagonistic consciousness. To challenge something or to lodge a complaint regarding personal grievances with that is the purport of this genre. However, we have observed that on the arrival of scripts the style of poetry has changed. But, that change has not been a bolt from the blue because the invention of scripts is not all about safeguarding the language of consciousness. Even after the introduction of scripts, memory was more important than writing due to the scarcity of writing materials. This led the humans to be dependent primarily on their memory. Crisis of this stature had not been present here in our part of the world before Nathaniel Brassey Halhed's printing press came into vogue two hundred years ago $^{11}$. In fact, the history of printing presses is not very long. Preserving knowledge became easier as soon as the printing press arose. It became so easy for the people concerned that the search for any information can be easily operated in any books. The onus of preserving writings went to the books as well as the individual. Prior to the invention of the printing press, poetry belonged to the mass. At that time, poetry did not revolve around the educated only. A person with a very little education was enough to spread the message contained in a poem since others were able to listen to his or her recitation. It is an irony that the printing press has made poetry divorce the mass. Poetry has become intensely personal. The metaphors along with other figurative features used in poetry have been out of control since then. Being subjective, poetry also lost its focus which previously centered on the magnanimous subjects related to a nation. The poets kept themselves busy in glorifying the trifle through their poems. With this glorification of the trivial things, poetry became devoid of the property of quenching the collective thirst. The aggression of the printing press on a wide scale orchestrated the separation of the illiterate from poetry; the entertainment of whom came from poetry in the past. The poet no longer became directly reader oriented. The poet now does not go to the doorstep of the readers. The practice of our age is to print thousands of copies of books full of the poems composed by the poet with a view to sending those material copies to the readers. Whether the readers read those poems or not can be the subject of another debate. The cycle of poetry revolved around the mutual pursuit of the poets as well as the readers

Page | 102 
in the days that preceded the printing press. Now, the readers are neglected by the poet in the course of creation and there remains no scope of adding or removing anything at a subsequent time $11^{12}$. The primary phase of weaving a poem carried forward mankind's perception and memory. Poetry was the transmitter of success and failure from one period to another. At the present time poetry does not have to hand down anything. So, it has become thoroughly personal. Drawing some examples from our Bengali poetry, this can be proved. The examples taken from the Charyapada show us that the personal interest has ceded its place to the collective welfare. Basically the Charyapada portrayed the humans of that particular time when they started evaluating their worth as a whole. The aim of the Charyapada was to connect to the universality crossing the barrier of individuality. There is no depiction of personal pain or suffering in these poems. The elements of life seen from a bigger perspective and the constituents of religion are graphically described in these poems. Over the eight hundred years of the medieval age, the structure of poetry has changed a little but no diversion has been found in the subject matter. The universality of the subject matter has immortalized the poetry of this age. It is often said that the epic poets leave their souls here in the world while passing away. Epics tell us the story of the period when humans were living in a strong group. At that time, the necessity of being united was uniquely important. In the post charyapada period, the stories of the folk deities as depicted in the Mangalkavya were the stories of survival. Even the lyrical poems of the Vaishnavite padavali delineate the suffering of the same soul inhabiting every creature $12^{13}$. The story which is found in these poems has been born by the humans by assimilating them with their consciousness about struggle and philosophy down the ages. Still I can not understand why today's poets bear a dream about immortality. These poets also want the readers to understand their poetry or to compare their perception and expression with the poets. On the part of today's poets, this is a kind of illogical desire. The lack of historical knowledge and the inability to observe the dynamics of various socio-economic classes enkindle this desire for immortality. It should be kept in our mind that today's poets write for themselves and their minority class. The use of the word 'class' can not be the appropriate word because class is what humans have lost in our age. In spite of the evolution of a wealth and consumer oriented class, the field of perception and consciousness has diversified now. The perception of today's poet is subjective only. If it resembles another poet, it becomes a minimization of thought. So, it is imperative to be in the know of the personal life of a modern poet in order to form an idea about him or her.
Modernity teaches us this. But the readers need not know the personal life of not only Homer and Shakespeare but also Alaol and Bharatchandra in a bid to taste their literary works. By reading their poetry, the readers could sharpen their experience, entertain themselves and find out the formulas of matching themselves with the world. Collectivism got the upper hand over individualism in those literary works. There is no fault if Hamlet becomes the master of a horse or the boy who run errands in a theater group. No fault is there also in Homer's blindness. Is there any fault in Valmiki's life as an acetic? The answer is 'no' since he has not limited the scope of his literary works by placing him inside. But understanding Rabindranath necessitates the presence of background knowledge inside the reader. The poetry of T.S Eliot throws the reader into the domain of history and myth. None of the two stands on their own feet. Their steps are on the soil of another territory and their readers hover in the sky of information. The people of this class are writing without maintaining any relation with poetry. Poetry is being extremely marginalized. Why do the poets clamor for poetry then? The reason which gave rise to the consciousness of poetry amid mankind is becoming irrelevant in our present age. Poetry's survival is like the organ of an animal which has been defunct in the evolutionary process. The people with a comparatively lower grade poetic license are becoming the script writers of our television channels overnight. Some of them have diverted their attention to the writing of novels. The others are frequenting the printing presses in order to relieve them of the delivery pain. Being undervalued in own country, a few of them are going abroad in order to buy the poetic fame from the so called entities.

Despite these, poetry is still victorious. The presence of poetry implies that our society has not been fully robotic yet. The texture of the rhythms, words and sentences of that poetry is not borrowed from the computer. That poetry will jumble even the certain way of happiness. Poetry will fight against itself then. The days of talking about the people who remains not only outside the customary rhythm and lexicon but also the people who follow either prosaic or mixed patterns are running out. Now, poetry is a kind of thinking which leads to perception. Perception can be expressed through various channels but no name should be applicable to it except poetry.

\section{REFERENCES}

1 The Republic, Plato, Oxford University Press

2 The Logic of Scientific Discover, Kal Popper, Routledge Classics, London and New York, 2002 
3 A Brief History of Poetry, Audrey Golden, books tell you why, 2015

4 Course in General Linguistics, Ferdianand de Saussure and Philosophy of Linguistics, Noam Chomsky

5 Existentialism, Jean Paul Sartre

6 Greek Civilization Character, edited by Arnold J. Toynbee

7 Mythology, Edith Hamilton, A Mentor Book, The New American Library

8 Palace of Illusions, Chitra Banerjee Divakaruni

9 Power of Myth, Joseph Campbell

10 Art, Science and Religions, Christina Payne

11 S. Natarajan: A history of the Press in India, (New York:

Asia Publishing House, 1962)

12 A History of Modern Poetry, David Perkins

13 History of Bangala Literature, Sukumar Sen 